DOI: 10.20472/EFC.2019.012.002

\title{
FILIP BAŠIĆ
}

Post-graduate student, Faculty of Economics and Business in Zagreb, Croatia

\section{CAN PRODUCTION OF ALCOHOL BEVERAGES PREDICT RECESSIONS?}

\begin{abstract}
:
Periods before the start of recessions are characterized by increased uncertainty and stress which are manifested by increase in alcohol consumption. The main idea behind this paper is that increased alcohol production follows this increase in consumption and thereby can be used as early warning indicator. The data was analysed through signal extraction approach that tests if specific indicator deviates significantly from its "normal" values and by doing so issues a warning signal about possible future recession. Analysis on production of three main alcohol types in four European countries shows good accuracy of indicators based on alcohol production but with significant inconsistency between countries. Inconsistency can be explained by alcoholic preference of specific country with indicators being far less precise in predicting recessions if they are based on least consumed alcohol type. Received results expand existing early warning methodology and give potential for further development by putting larger focus on human behaviour in predicting recessions. Also, these findings have important policy implications since early recognition of upcoming recession significantly aids in reducing its effects and duration.
\end{abstract}

\section{Keywords:}

recession, early warning indicators, alcohol consumption, drinking habits

JEL Classification: E37 


\section{Introduction}

After the great recession in 2008. there have been discussions why most of existing early warning indicators didn't predict the recession on time. Early warning indicators rely on detecting some sort of disturbance in the economy which precedes the recession. Research of Caroll (1992), Eberly (1994), Hengge (2019) and others showed that increased uncertainty in the economy successfully predicts decline of economic activity. Following their research,this paper aims to explore how the increase of alcohol consumption, as a consequence of increased uncertainty and stress inthe economy, can be used to predict recessions. To estimate alcohol consumption of specific country, supply-utilisation model will be used which evaluates consumption according to collected data on produced alcohol beverages.

Analysis is made by signal extraction approach on specificindicators based on production of different types of alcoholic beverages in Germany, Greece, Spain and France. Signal extraction approach analyses if indicator deviates significantly from its "normal“ values and by doing so issues a warning signal about possible future recession(Ahec - Šonje 1999). Performance of indicators will be tested by calculating noise-to-signal ratio which positively values correct predictions but at the same time penalizes false and missed signals. Also, the research will focus on additional factors that may affect performance of indicators.

The remainder of the paper is organized as follows. Paper begins withoverview of early warning methodology and how alcoholic consumption present potential for further growth. Next section gives explanation of used methodologywhich is followed by presenting received results and their real-life implications. Last chapter provides summary and offers recommendationsfor future research.

\section{Early warning indicators}

Modern economies oscillate between phases of expansion and recession. During expansion, economic activity grows, unemployment is generally low, standards of living tend to rise which significantly contributes to overall happiness. However, expansions are followed by the periods of time when economy is experiencing decline in activity across a large number of sectors. They often start suddenly and are hard to predict. During recessions many companies find themselves in financial problems and are forced to cut costs. Labour force is quite often first on the hit. Recessions are characterised by higher probability of unemployment and lower wage growth(Berge 2014) which consequently increases uncertainty and stress levels of people.

However, by early recognising upcoming recession, it's effects and duration can be reduced. Many economists point out the significance of monetary and fiscal policy in stabilisation of economy and reducing negative effects of recession (Saliba 2013). Therefore, a lot of authors have focused their research on different ways of predicting recessions. The literature dates back to the 1970s, when first time leading indicators (Bilson, 1979) and similar theoretical models (Krugman, 1979) generate interest of several researchers. But, further progress in the field was quite slow till the 1990s when methodological debate started with the studies on currency crises (Frankel and Rose, 1996) and on banking and balance-of-payments problems (Kaminsky andReinhart, 1996).

The1990s was the first golden era of the early warning literature but many of the generated methodology did not gain enough credibility to be transferable to the next generation of early 
warning models because their accuracy were not stable to gain the interest of policymakers (Berg and Pattillo, 1999b). Accuracy of models would significantly change when used on different country samples (developed, emerging, or developing), timeperiods (1950s-2010s) or types of recessions (Christofides 2016). That is, lessons learned from one recession and country may not be relevant for another.

In the last 30 years literature generated many different indicators for predicting business cycle turning points. For instance, yield curve indicator is focusing on relationship between bond yields and bond maturity and is one of the most recognised and most used indicators (see, e.g.,Estrella \& Mishkin, 1998; Kauppi \&Saikkonen, 2008; and Rudebusch \& Williams,2009). There are many more different financial and macroeconomic indicators that provide useful signals on future state of the economy, however the empirical work on indicators for predicting recessions faces a problem of selection bias. Thevariables examined as indicators are selected with the benefit of hindsight, although normally basedon some underlying economic reasons. Therefore, even if the result were statistically significant, usefulness of indicators may be questionable if they have been discovered after the recession (Frankel \&Saravelos 2012).

\section{Predicting recession with alcohol consumption}

Indicators for predicting recessions try to detect some sort of disturbance in the economy that signals possible recession in near future. In this paper, focus will be on alcohol consumption as a possible indicator for predicting recessions, as it may efficiently capture uncertainty and stress in the economy. Alcohol beverages are interesting case because although they classify as normal goods for most individuals, they alsopossess mood-altering, medicinal, and addictive properties. (Davalos et al., 2012).

Set of studies have found that increase of uncertainty in the economy is a good sign of upcoming recession. For instance, Hengge (2019) points out that macroeconomic uncertainty successfully predicts downside risks to economic activity. Furthermore, economic agents, when faced with rising uncertainty inthe system, tend to lower their economic activity by increasing precautionary savings (Carroll, 1992), implementing "wait and see" strategies (Eberly, 1994) or by temporarily pausingthe processof investing and hiring (Bloom, 2009).

Following situation has two significant effect on alcohol consumption. Primarily, pausing the process of investing and hiring will affect labour market and increase the unemployment rate. Several studies have proved that unemployment creates a situation of financial strain, which induces the individuals to canalize stress through increased alcohol consumption (Peirce et al., 1994).For instance, positive correlation was proven between unemployment and alcohol consumption (Kessler et al., 1987), unemployment and alcohol abuse (Crawford et al., 1987), unemployment and psychological problems from alcohol abuse (Catalano et al., 1993).

However, it needs to be noted that some studies didn't discover correlation or even reported negative correlation between increase in unemployment and alcohol consumption (Ettner, 1997; Rhum and Black,2002). This is mostly as a consequence of pure income effect, where reductions in income of unemployed drinkers cause them to cut back on their drinking alcohol or even stop completely with alcohol consumption (Davalos et al., 2012).On the other hand, research of Dee (2001) has shown that unemployment leads to less alcohol consumption but to more risky patterns of drinking. The best overall conclusion could probably be taken from 
the research of Cotti, Dunn and Teft (2014) who have included economic situation in their analysis. Their result indicate that unemployment rate is associate with significant change in alcohol purchases when the economy is in a good condition, but these effects fade as the situation in the economy worsens.

Second effect on alcohol consumption comes from lowering economic activities by economic agents, which along with overall uncertainty in the economy, tend to affect employees and increase their stress levels. There is a wide variety of evidence suggesting thatthe alcohol consumption increases in response to job related stress (Martin and Roman 1996; Lehman et al. 1995). Also, depression, as a possible more grave consequence of job related stress, is positively related to alcohol consumption (Hartka et al., 1991).

To sum up, alcohol consumption is widely viewed as one of the main means of easing the pain ofemployment problems, emotional distress and anxiety, financial hardship (Hill and Angel, 2005; Pierce et al., 1994) and job-related stress (Dee 2011).Therefore, it represents great potential for predicting recession as it successfully captures the uncertainty and stress that precedes the recession.Apart from analysing the usefulness of alcohol consumption as recession indicator, this paper will also cover the effects and accuracy of different types of alcohol. For that purpose, alcohol beverages will be divided in three main groups: wine, beer and spirits. Spirits category will include distilled, potable, alcoholic beverages (e.g. whisky, brandy, gin, liqueurs), drinks mixed with distilled alcoholic beverages and blending of distilled alcoholic beverages.

\section{Measuring alcohol consumption}

Measuring alcohol consumption of specific country can be quite challenging especially when monthly data is required. Leifman, Österberg and Ramstedt (2002) identify two main data sources for measuring alcohol consumption. One is the official statistics of alcohol consumption while the other consists of representative population survey data of alcohol consumption. Population survey data usually provides a larger amount of data since it includes different measures of drinking patterns such as share of heavy drinkers, abstinence rates,proportion of alcohol consumed during meals and similar (Leifman, Österberg\&Ramstedt, 2002).

Several studies have shown that individual purchasing decisions are strongly associated with his future consumption behaviour (Amlung et al. 2012; Murphy et al. 2009; MacKillop and Murphy 2007). Thereby, alcohol consumption can be estimated from sales data of alcohol beverages. There are three different models for collecting sales data of alcohol beverages (Leifman, Österberg\&Ramstedt, 2002):

- The tax records model - This model can only be used in countries where alcoholic beverages are taxed, and is usually based on excise duties.

- The retail sale and wholesale model - This model is characteristic for Nordic European countries that have a retail monopoly system for off-premises sale of most alcoholic beverages (Holder et al., 1998;Österberg\& Karlsson, 2002).

- The supply-utilisation model -In this model estimation of alcohol consumption is made according to collected data on produced alcohol beverages. 
In this paper supply-utilisation model will be used and the data will be collected from the online database of Eurostat, the statistical office of the European Union. However, there are few problems when alcohol consumption is measured by supply-utilisation model.

Firstly, generalisation is quite difficult in the supply-utilisation model because countries, apart from above mentioned model, may also use some sort of survey method to estimated alcohol consumption value (Room 1999). Using data from single database of Eurostat, with uniform methodology, will alleviate this problem and enable comparability of data between different countries in the sample.

Another problem is assigning household purchases to individual consumption as well as assigning purchased alcohol to specific periods. A large purchase of alcohol could reflect larger consumption but it could also reflect that householdsare stockpiling alcohol because of a sale (alcohol is consumed responsibly over a long time period) or that a household member plans on binging for several days (Cotti, Dunn \&Teft, 2014).

Special problem is unrecorded consumption that is estimated to make about $13 \%$ of all alcohol consumed in the European union (Shield et al., 2012). This is significant percentage, but still much lower than global average of almost $30 \%$ of all alcohol consumed being unrecorded (Lachenmeier, Taylor \& Rehm, 2011). Main reasons for unrecorded alcohol consumptions can be grouped in six categories:

- Alcoholic beverages produced privately at home,

- Alcoholic beverages consumed during visits to other countries,

- Alcohol imported by travellers,

- Smuggled alcoholic beverages,

- Surrogate alcohol,

- Beverages containing alcohol but not defined as alcoholic beverages.

In this report import and export of alcohol beverages will be ignored because they aren't divided by alcohol type categories which is necessary for the overall analysis. This is a little defect of the analysis but it also represents advantage because calculated recession indicators will also capture the current state of alcohol production industry of specific industry which would not be possible if imports and exports are included.

\section{Data and methodology}

As outlined in the previous section, there are problems with data availability when analysing alcohol production of specific European country on a monthly basis. For most countries data has been published for last ten years which is insufficient for using in the model because the great recession in 2008 cannot be adequately analysed. For that reason, data set only covers 4 countries with longer data periods: Germany, Greece, France and Spain. They will also provide additional insight about using alcohol consumption as early warning indicator because of their cultural differences and different drinking habits. For those countries, movements in production of different types of alcohol beverages have been estimated by specific indexes:

- Distilling, rectifying and blending of spirits (Figure 1),

- Manufacture of wine from grape (Figure 2),

- Manufacture of beer (Figure 3). 
To prevent significant oscillations within one year, which would prevent analysis of indicators and their accuracy, seasonally and calendar adjusted values of index have been used.

To find out if change in alcohol consumption is a good indicator of upcoming recession and if some types of alcohol are more precise than others, non-parametric technique of signal extraction approach will be used, following the work of Kaminsky, Lizondo, and Reinhart (1998), Kaminsky and Reinhart, (1999), Berg and Pattillo (1999a and 1999b), Edison (2003) Basu et al. (2017) and others. It needs to be noted that other methods for generating future predictions of crisis or recessions exist, for instance probit regression used by Frankel and Rose (1996), Berg and Pattillo (1999b) andKamin and Babson (1999). However, the signal extraction approach (also known as the indicators approach) will be used because calculations and thresholds are relatively simple to interpret and it doesn't prevent calculating thresholds if data for some months are missing, but just makes that indicator's threshold is less precisely calculated.

Signal extraction approach analyses if specific indicator deviates significantly from its "normal“ values and by doing so issues a warning signal about possible future recession. To successfully use this approach signalling horizon, threshold level and signals classification first need to be defined. Signalling horizon is a period before the start of recession in which specific indicator should issue warning signals. Signalling horizon can vary from 12 to 24 months, but most authors pick 18 months before the start of recession (Ahec - Šonje 1999). 18 months will also be used in this paper. Recession periods will be determined by "classic" method of two consecutive quarters of negative economic growth, measured by seasonally and calendar adjusted real gross domestic product(real GDP).

The threshold levels should be set to achieve balance between the risks of having many „bad“ signals and the risk of missing many recessions. For each indicator there are four possible scenarios (see table 1):

- Scenario A - a "good" signal is issued followed by recession in next 18 months (signalling horizon),

- Scenario B - indicator issues a signal but no recession occurs,

- Scenario C - signal is not issued but recession nevertheless occurs,

- Scenario D - signal is not issue nor the recession occurs.

Table 1. Performance of the indicator

\begin{tabular}{|l|c|c|}
\hline & Recession occurs & No recession \\
\hline Signal appears & A & B \\
\hline No signal & C & D \\
\hline
\end{tabular}

Source: Ahec-Šonje, A. (1999.), Navješćujućiindikatorivalutnihibankarskihkriza: Hrvatska isvijet, Ekonomskipregled : mjesečnikHrvatskogdruštvaekonomista, 50(9): 1077-1113

For determining threshold value for each indicator, noise-to-signal ratios need to be minimized according to the following formula: $[B /(B+D)] /[A /(A+C)]$. This is done by a grid search in which noise-to-signal ratios are calculated for a range of potential values and the value which minimizes the noise-to-signal ratio is chosen for threshold value. In the analysis, monthly 
values of alcohol consumption will be determined for each country, and then for every percentileof the sample, threshold values will be calculated. However, threshold values for percentiles above 950 will be ignored because they produce too few signals.

The perfect indicator would have noise-to-signal ratio of 0 because there would be no $B$ scenarios. On the other hand, „bad“ indicator would have zero scenarios A, and the noise-tosignal ratio would be infinity. Normally, results fall somewhere between these two extremes. Noise-to-signal positively values correct predictions but at the same time penalizes false and missed signals. This allows fair ranking of indicators and prevents situations in which indicator would be chosen as top performer by one criteria while at the same time performing poorly by other criteria.

\section{Performance of the indicators across countries}

For every country in the sample (Germany, Greece, Spain, France) three early warning indicators will be analysed. Performance of each indicator will be assessed by previously described noise-to-signal ratio and additionally by share of recessions in which the indicator signals at least once within the signalling horizon.

Table 2 shows results for wine production indicator. There is significant difference in performance of the indicator between analysed countries. It shows great precision for France with low noise-to-signal ratio (0.131) and fair share of recessions called but at the same time seems to be completely unreliable for use in Germany.

Table 2. Wine production indicator

\begin{tabular}{|l|c|c|c|c|}
\hline & $\begin{array}{c}\text { Number of } \\
\text { observations }\end{array}$ & $\begin{array}{c}\text { Share of } \\
\text { recessions called }\end{array}$ & $\begin{array}{c}\mathrm{P} \text { (Recession } \\
\text { /signal) }^{2}\end{array}$ & $\begin{array}{c}\text { Noise-to- } \\
\text { signal ratio }^{3}\end{array}$ \\
\hline Germany & 315 & 0.8 & 0.28 & 0.931 \\
\hline Greece & 210 & 0.33 & 0.53 & 0.303 \\
\hline Spain & 186 & 0.5 & 0.38 & 0.384 \\
\hline France & 318 & 0.67 & 0.5 & 0.131 \\
\hline
\end{tabular}

Note: 1. Number of recession for which indicator issued at least one signal during the 18 months prior to the recession; 2. Probability of a recession: $A /(A+B) ; 3$. Ratio of false signals to total number of months there is no crisis relative to proportion of good signals

Source:Author's calculation

Inconsistency between countries is also shown in beer production indicator (Table 3) and spirits production indicator (table 3). Beer production indicator for Spain scores lowest overall value of noise-to-signal ratio (0.120) with giving signals for all recessions. It is also quite reliable for usage in Germany but its performance degrades in Greece and France. Similarly, spirits production index shows good results for France and Germany but becomes unreliable for use in Greece and especially Spain (Table 4). 
Table 3. Beer production indicator

\begin{tabular}{|l|c|c|c|c|}
\hline & $\begin{array}{c}\text { Number of } \\
\text { observations }\end{array}$ & $\begin{array}{c}\text { Share of } \\
\text { recessions called }\end{array}$ & $\begin{array}{c}\mathrm{P} \text { (Recession } \\
\text { /signal) }\end{array}$ & $\begin{array}{c}\text { Noise-to-signal } \\
\text { ratio }\end{array}$ \\
\hline Germany & 315 & 0.4 & 0.6 & 0.242 \\
\hline Greece & 210 & 1 & 0.31 & 0.779 \\
\hline Spain & 186 & 1 & 0.67 & 0.120 \\
\hline France & 318 & 0.33 & 0.25 & 0.614 \\
\hline
\end{tabular}

Source: Author's calculation

Table 4. Spirits production indicator

\begin{tabular}{|l|c|c|c|c|}
\hline & $\begin{array}{c}\text { Number of } \\
\text { observations }\end{array}$ & $\begin{array}{c}\text { Share of } \\
\text { recessions called }\end{array}$ & $\begin{array}{c}\mathrm{P} \text { (Recession } \\
\text { /signal) }\end{array}$ & $\begin{array}{c}\text { Noise-to-signal } \\
\text { ratio }\end{array}$ \\
\hline Germany & 315 & 0.4 & 0.64 & 0.202 \\
\hline Greece & 210 & 0.33 & 0.46 & 0.404 \\
\hline Spain & 186 & 1 & 0.24 & 0.772 \\
\hline France & 318 & 1 & 0.28 & 0.136 \\
\hline
\end{tabular}

Source: Author's calculation

When combining results for all four countries it is interesting that every country has two "good" indicators with noise-to-signal ratio 0.4 or below and one "bad" indicator with noise-to-signal ratio above 0.6 (table 5). Quite low values of noise-to-signal ratios present big potential for early warning indicators based on alcohol productionbut without further analysis of factors that may influence their inconsistency between countries, their real-life usage may be quite questionable. Thereby, in the next section drinking patterns of countries in sample will be analysed and connected to performance of specific indicators.

Drinking patterns may be analysed by many different ways. For example, by the frequency of consumption, types of alcohol, place where alcohol is drunk (e.g. bar, home), context of consumption (e.g. with meals) and similar. However, there are some problems when analysing drinking patterns. Anderson and Baumberg (2006) point out that necessary data is often missing. Also, selection and weighting of data used for creation of pattern variable is usually unclear which leads to analysis which is in great amount relying on expert evaluation.

To get better insight in drinking patterns of countries in sample, focus will be on put on preferred types of alcoholic beverages. Shield et al. (2012). point out that in Central-western and western Europe, region with high GDP beer is preferred beverage in all countries except France. On the other hand, southern Europe (Portugal, Spain, Italy, Greece) are characterized 
by Mediterranean drinking pattern where wine is traditionally produced and consumed (Anderson \&Baumberg, 2006). This is in line with the research of Bentzen, Eriksson \& Smith (2001) who defined France, Spain and Greece as wine countries and Germany as beer country.

Figure 4 shows estimated consumption expenditure of private household on different types of alcohol. It confirms that Greece citizens mostly consume wine followed by spirits. This is in line with performance of indicators for different types of alcohol. Wine production indicator had been most precise, also followed by spirits production indicator. Similar situation is in France, where wine is most consumed alcohol beverage and wine production indicator is most precise. On second place, are again spirits consumption and spirit production indicator.

In Spain however, best performing indicator is for beer production followed by wine production indicator. Spain was traditionally described as wine country but data of private households expenditure show similar expenditure on beer and wine. Moreover, Anderson \&Baumberg (2006) have shown in their research that Spain has started to drink more beer than wine.

Figure 4. Structure of consumption expenditure of private households per mille (2015)

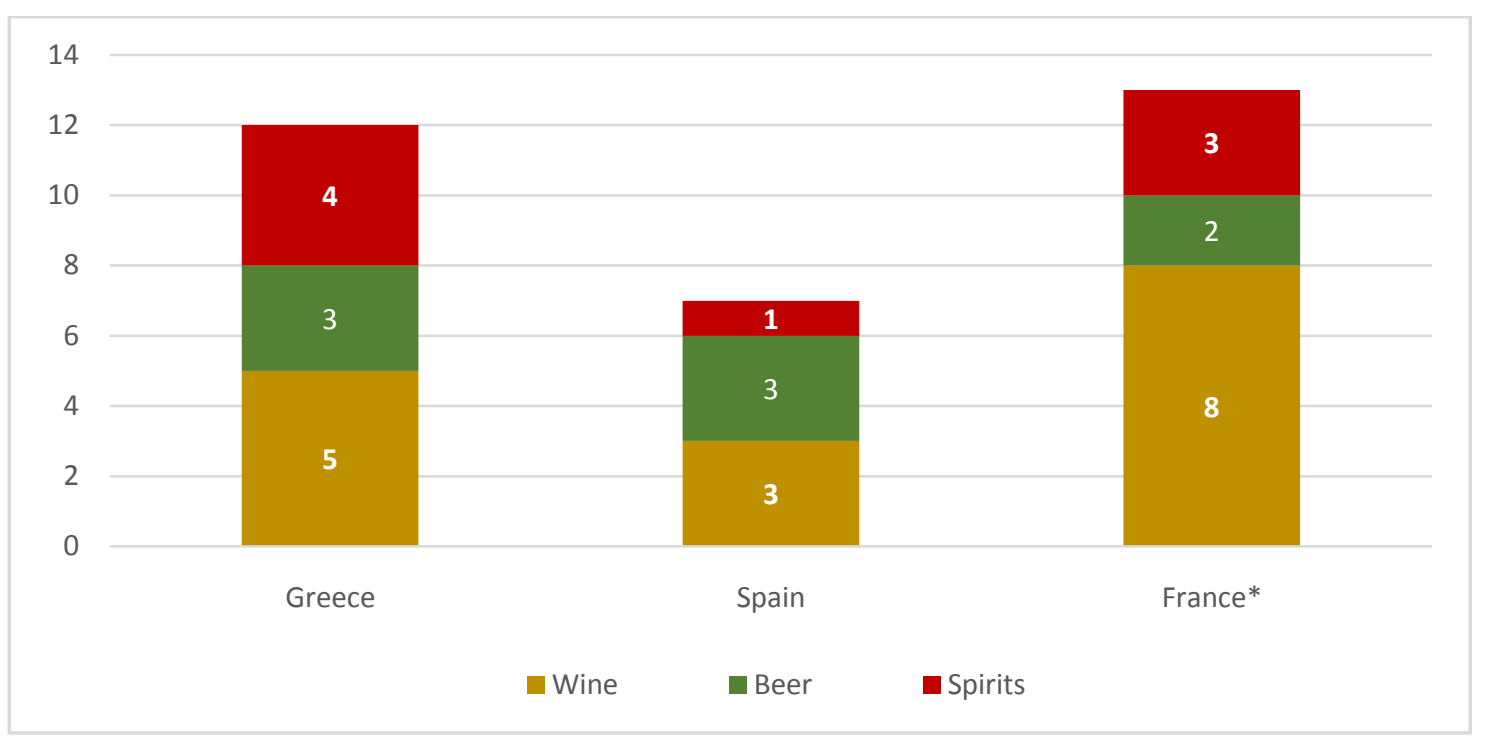

*Note: Data for 2010.

Source: Eurostat (2019b.), Structure of consumption expenditure by COICOP consumption purpose, available at: https://ec.europa.eu/eurostat/web/household-budget-surveys/database [20 April 2019]

Structure for Germany can be taken from the research of Leifman, Österberg and Ramstedt (2002) who estimated that beer is most consumed alcohol beverage $(46 \%)$ followed by spirits $(33 \%)$ and wine (18\%). Again, previously calculated indicators for two most consumed alcohols show good results, with spirits indicator being slightly better, whereas indicator for least consumed alcohol beverage is highly unreliable.

Thereby, after calculating early warning indicators based on alcohol production for Germany, Greece, Spain and France and analysing their drinking habits it is possible to conclude that performance of specific early warning indicator for some country is under the effect of alcohol type preference in that country. Received results show that indicator is far less precise in 
predicting recessions if it is based on alcohol type that is least consumed in specific country, for example wine production indicator in Germany.

\section{Conclusion}

In the last 30 years, many authors have tried to predict periods of recessions with different types of early warning indicators. In theory, early warning indicators should generate specific signals of upcoming recession but great recession in 2008 showed that existing indicators are still not completely accurate in their predictions.

This paper shows potential of early warning indicators based on alcohol beverages production by focusing on production data in Germany, Greece, Spain and France. These indicators are trying to estimate alcohol consumption of specific types of alcohol beverages and detect periods of increased consumption. Varied studies from several disciplines have suggested that increased alcohol consumption often is a sign of financial hardship, emotional problems, job-related stress which precede the recession. Received results on three main alcohol categories show good precision of indicators measured by noise-to-signal ratio but with large inconsistency between countries in the sample.Combining received results with alcoholic preference of specific country, demonstrated that indicators tend to be far less precise in predicting recessions if they are based on least consumed alcohol type.

The policy implications of this research are both timely and alarming. If alcohol consumption rises during period of two years before the emergence of a recession, then monetary and fiscal measures can be used to stabilise situation in economy and reduce negative effects of upcoming recession. Some governmental bodies are already keeping eye on specific early warning indicators and including alcohol consumption in their analysis could further improve their insight.

There are few limitations of research that need to be addressed. Firstly, due to lack of data for longer time periods, sample is based on only four developed European countries. Received results may be different for less developed countries or for the non-European countries. Also, research ignores the effect of import and export of alcoholic beverages, mostly because, for countries in sample, consumption of alcoholic beverages comes from their own production. Thereby, further research should be focusing on analysing performance of early warning indicators based on alcoholic beverages on a wider sample of countries as well as analysing effects on countries that mostly import alcoholic beverages. 


\section{References:}

Ahec-Šonje, A. (1999.), Navješćujućiindikatorivalutnihibankarskihkriza: Hrvatska isvijet, Ekonomskipregled: mjesečnikHrvatskogdruštvaekonomista, 50(9): 1077-1113

Anderson, P., Baumberg., B. (2006.), Alcohol in Europe - Public health perspective, Drugs: education, prevention and policy, 13(6): 483-488

Amlung, M., Acker, J., Stojek, M., Murphy, J. G., MacKillop, J. (2012.), Is Talk ‘Cheap'? An Initial Investigation of the Equivalence of Alcohol Purchase Task Performance for Hypothetical and Actual Rewards,Alcoholism: Clinical and Experimental Research, 36(4): 716-724

Babecký, J., Havránek, T.,Matějů, J., Rusnák, Rusnak, M., Šmídková, K.,Vašíček, B. (2013.), Leading indicators of crisis incidence: Evidence from developed countries, Journal of International Money and Finance, 35(C): 1-19

Basu, S., Chamon, M., Crowe, C. (2017.), A Model to Assess the Probabilities of Growth, Fiscal, and Financial Crises, IMF Working Papers, 17/282

Bentzen, J., Eriksson, T., Smith, V. (2001.), Alcohol Consumption in European Countries Time series based tests of convergence, Cahiers d'économie et sociologie rurales, 60-61: 5974

Berg, A., Pattillo, C. A. (1999a.), Predicting currency crises: the indicators approach and an alternative, Journal of International Money and Finance, 18(4): 561-586

Berg, A., Pattillo, C. A.(1999b.), Are currency crises predictable? A test, IMF Staff Papers, 46(2): 107-138

Berg, A., Borensztein, E., Pattillo, C. A. (2005.), Assessing Early Warning Systems: How Have They Worked in Practice?, IMF Staff Papers, 52(3): 462-502

Berge, T. J. (2015.), Predicting Recessions with Leading Indicators: Model Averaging and Selection Over the Business Cycle, Journal of Forecasting, 34(6), 455-471

Bilson, J. F. O. (1979.), Leading Indicators of Currency Devaluations, Columbia Journal of World Business, 14: 62-76

Bloom, N. (2009.), The impact of uncertainty shocks, Econometrica, 77(3): 623-685

Carroll, C.D. (1992.), The Buffer Stock Theory of Saving: Some Macroeconomic Evidence, Brooking Papers on Economic Activity, 23(2): 61-156

Catalano, R., Cooley, D., Wilson, G., Hough, R., (1993.), Job loss and alcohol abuse: a test using data from the epidemiologic catchment area project, Journal of Health and Social Behaviour, 34(3): 215-225

Christofides, C.,Eicher, T.,Papageorgiou, C. (2016.), Did established Early Warning Signals predict the 2008 crises?, European Economic Review, Elsevier, 81(C): 103-114

Cotti, C., Dunn, R. A., Tefft, N. (2015.), The Great Recession and Consumer Demand for Alcohol: A Dynamic Panel-Data Analysis of US Households, American Journal of Health Economics, 1(3): 297-325 
Crawford, A., Plant, M. A., Kreitman, N., Latcham, R. W. (1987.), Unemployment and drinking behaviour: some data from a general population survey of alcohol use,British Journal of Addiction, 82(9): 1007-1016

Davalos, M. E., Fang, H., French, M. T. (2012.), Easing the pain of an economic downturn: Macroecomic conditions and excessive alcohol consumption, Health Economics,21(11): $1315-1335$

Dee, T. S. (2001.), Alcohol abuse and economic conditions: evidence from repeated crosssections of individual-level data, Health Economics, 10(3): 257-270

Eberly, J. (1994.), Adjustment of Consumers' Durables Stocks: Evidence from Automobile Purchases, Journal of Political Economy,102(3): 403-436

Edison, H. J. (2003.), Do Indicators of Financial Crises Work? An Evaluation of an Early Warning System, International Journal of Finance \& Economics, 8(1): 11-53

Estrella, A., Mishkin, F. S. (1998.), Predicting u.s. recessions: Financial variables as leadingindicators, The Review of Economics and Statistics, 80(1): 45-61

Ettner, S. L. (1997.), Measuring the human cost of a weak economy: does unemployment lead to alcohol abuse?,Social Science Medicine, 44(2): 251-260

Eurostat (2019a.), Production in industry - monthly data, available at: http://appsso.eurostat.ec.europa.eu/nui/show.do?dataset=sts_inpr_m\&lang=en [23 April 2019]

Eurostat (2019b.), Structure of consumption expenditure by COICOP consumption purpose, available at: https://ec.europa.eu/eurostat/web/household-budget-surveys/database [20 April 2019]

Forcier, M. W.(1988.), Unemployment and alcohol abuse: a review, Journal of Occupational Medicine, 30(3): 246-251

Frankel, J. A.,Rose, A. K. (1996.), Currency Crashes in Emerging Markets: An Empirical Treatment, Journal of International Economics,41(3-4): 351-366

Frankel, J. A., Saravelos, G. (2012.), Are Leading Indicators of Financial Crises Useful for Assessing Country Vulnerability? Evidence from the 2008-09 Global Crisis, Journal of International Economics,87(2): 216-231

Hartka, E., Johnstone, B., Leino, E., Motoyoshi, M., Temple, M., Middleton, K., (1991.), A meta-analysis of depressive symptomatology and alcohol consumption over time, British Journal of Addiction,86(10): 1283-1298

Glick, R., Rose, A. K.(1999.), Contagion and trade: Why are currency crises regional?, Journal of International Money and Finance, 18(4): 603-618

Hengge, M. (2019.), Uncertainty as a Predictor of Economic Activity, available at: http://martinahengge.com/files/JMP MartinaHengge.pdf [23 April 2019]

Hill, T. D., Angel, R. J. (2005.), Neighborhood disorder, psychological distress, and heavy drinking, Social Science \& Medicine, 61(5): 965-975 
Holder, H. D., Kuhlorn, E., Nordlund, S., Öserberg, E., Romelsjo, A.,Ugland,T. (1998.), European Integration and Nordic Alcohol Policies. Changes in Alcohol Controlsand Consequences in Finland, Norway and Sweden, 1980-1997, Ashgate, Aldershot

Kamin, S., Oliver, B. (1999.), The contribution of domestic and external factors to Latin American devaluation crises: An early warning systems approach,International Finance Discussion Papers from Board of Governors of the Federal Reserve System (U.S.), No 645

Kaminsky, G. L., Reinhart, C. M. (1999.), The Twin Crises: The Causes of Banking and Balance-of-Payments Problems, American Economic Review, 89(3): 473-500

Kaminsky, G., Saul, L., Carmen, R. (1998.), Leading indicators of currency crises, International Monetary Fund Staff Papers, 45(1): 1-48

Kauppi, H.,Saikkonen, P. (2008.), Predicting u.s. recessions with dynamic binary response models, The Review of Economics and Statistics, 90(4): 777-791

Kessler, R., Turner, J. B., House, J. S. (1987), Intervening processes in the relationship between unemployment and health, Psychological Medicine, 17(4): 949-961

Krugman, P. (1979.), A Model of Balance-of-Payments Crises, Journal of Money, Credit and Banking, 11(3): 311-325

Lachenmeier, D. W., Taylor, B. J., Rehm, J. (2011.), Alcohol under the radar: do we have policy options regarding unrecorded alcohol?, International Journal of Drug Policy, 22(2):153-160

Leifman, H., Österberg, E., Ramstedt, M. (2002.), Alcohol in postwar Europe: A discussion of indicators on consumption and alcohol-related harm, European Comparative Alcohol Study - ECAS, Stockholm

Lehman, W.E.,Farabee, D.,Holcom, M., Simpson, D.D. (1995.), Prediction of substance abuse in the workplace: Unique contributions of personal background and work environment variables, Journal of Drug Issues, 25(2): 253-274

Martin, J.K., Roman, P. (1996.), Job satisfaction and drinking among employed persons, Work and Occupations, 23(1): 115-142

Murphy, J. G., MacKillop, J., Skidmore, J. R., Pederson, A. A. (2009.), Reliability and Validity of a Demand Curve Measure of Alcohol Reinforcement, Experimental and Clinical Psychopharmacology, 17(6): 396-404

Österberg, E., Karlsson, T. (2002.), Alcohol Policies in EU Member States andNorway, A Collection of Country Reports, Stakes, Helsinki

Peirce, R. S., Frone, M. R., Russell, M., Cooper, M. L.(1994.), Relationship of financial strain and psychosocial resources to alcohol use and abuse: the mediating role of negative affect and drinking motives, Journal of Health and Social Behaviour, 35(4): 291-308

Rudebusch, G. D., Williams, J. C. (2009.), Forecasting recessions: the puzzle of the enduringpower of the yield curve, Journal of Business \& Economic Statistics, 27(4): 492503 
Ruhm, D. J., Black, W. E. (2002.), Does drinking really decrease in bad times?, Journal of Health Economics, 21(4): 659-678

Room, R. (1999.), The idea of alcohol policy, Nordic Studies on Alcohol and Drugs, 16(1): 720

Saliba, C. (2013.), The role of monetary policy in the economic recovery following the 20082009 global financial crisis, Bank of Valletta Review, No. 47

Shield, K. D., Kehoe, T., Gmel, G., Rehm, J. (2012.), Societal burden of alcohol, Alcohol in the European Union. Consumption, harm and policy approaches, World Health Organization Regional Office For Europe, Copenhagen 


\section{Appendices}

Table 5. Overview of noise-to-signal ratios per countries and types of indicators

\begin{tabular}{|c|c|c|c|}
\hline & \multicolumn{3}{|c|}{ Indicator } \\
\hline & $\begin{array}{c}\text { Spirits } \\
\text { production }\end{array}$ & $\begin{array}{c}\text { Wine } \\
\text { production }\end{array}$ & $\begin{array}{c}\text { Beer } \\
\text { production }\end{array}$ \\
\hline Germany & 0.202020202 & 0.931263858 & 0.242424242 \\
\hline Greece & 0.403846154 & 0.302884615 & 0.778846154 \\
\hline Spain & 0.772173913 & 0.384 & 0.12 \\
\hline France & 0.136363636 & 0.131493506 & 0.613636364 \\
\hline
\end{tabular}

Source: Author's calculation 
27 August 2019, 12th Economics \& Finance Conference, Dubrovnik

ISBN 978-80-87927-80-9, IISES

Figure 1. Distilling, rectifying and blending of spirits, Index $(2015=100)$

300

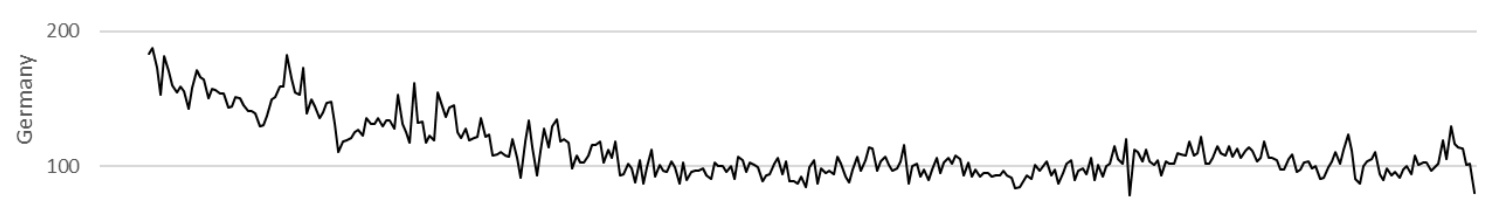

$\begin{array}{llllllllllllllllllllllllllllllll}90 & 91 & 92 & 93 & 94 & 95 & 96 & 97 & 98 & 99 & 00 & 01 & 02 & 03 & 04 & 05 & 06 & 07 & 08 & 09 & 10 & 11 & 12 & 13 & 14 & 15 & 16 & 17 & 18\end{array}$

300

200

100

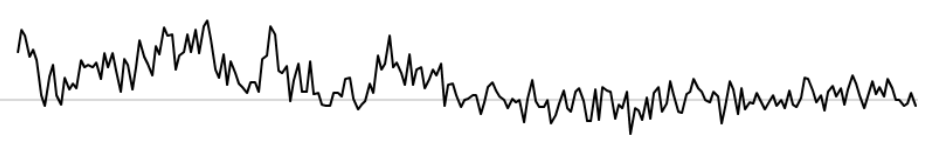

$\begin{array}{lllllllllllllllllllllllllllll}90 & 91 & 92 & 93 & 94 & 95 & 96 & 97 & 98 & 99 & 00 & 01 & 02 & 03 & 04 & 05 & 06 & 07 & 08 & 09 & 10 & 11 & 12 & 13 & 14 & 15 & 16 & 17 & 18\end{array}$

300

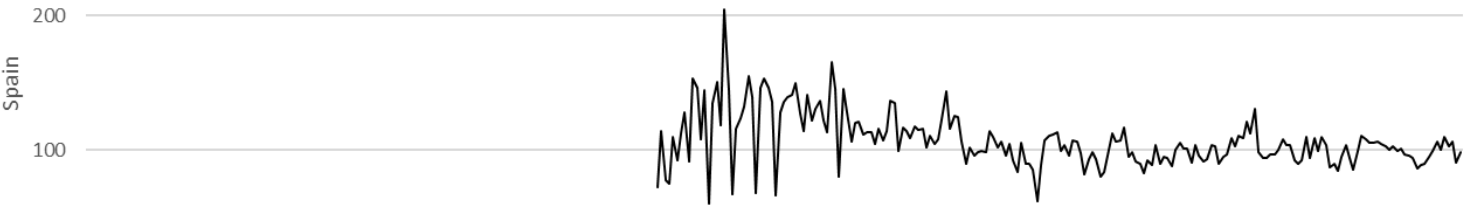

$\begin{array}{llllllllllllllllllllllllllllll}90 & 91 & 92 & 93 & 94 & 95 & 96 & 97 & 98 & 99 & 00 & 01 & 02 & 03 & 04 & 05 & 06 & 07 & 08 & 09 & 10 & 11 & 12 & 13 & 14 & 15 & 16 & 17 & 18\end{array}$

300

200

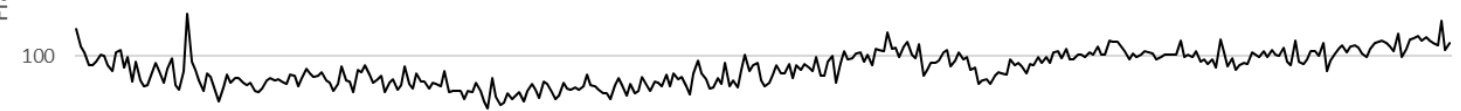

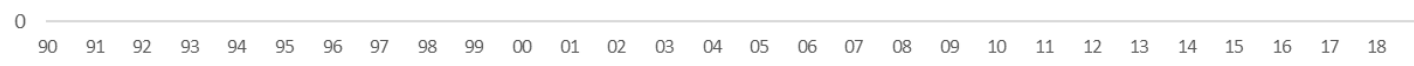

Source: Eurostat (2019a.), Production in industry - monthly data, available at: http://appsso.eurostat.ec.europa.eu/nui/show.do?dataset=sts intr m\&lang=en [23 April 2019]

https://iises.net/proceedings/12th-economics-finance-conference-dubrovnik/front-page

28 
Figure 2. Manufacture of wine from grape, Index $(2015=100)$

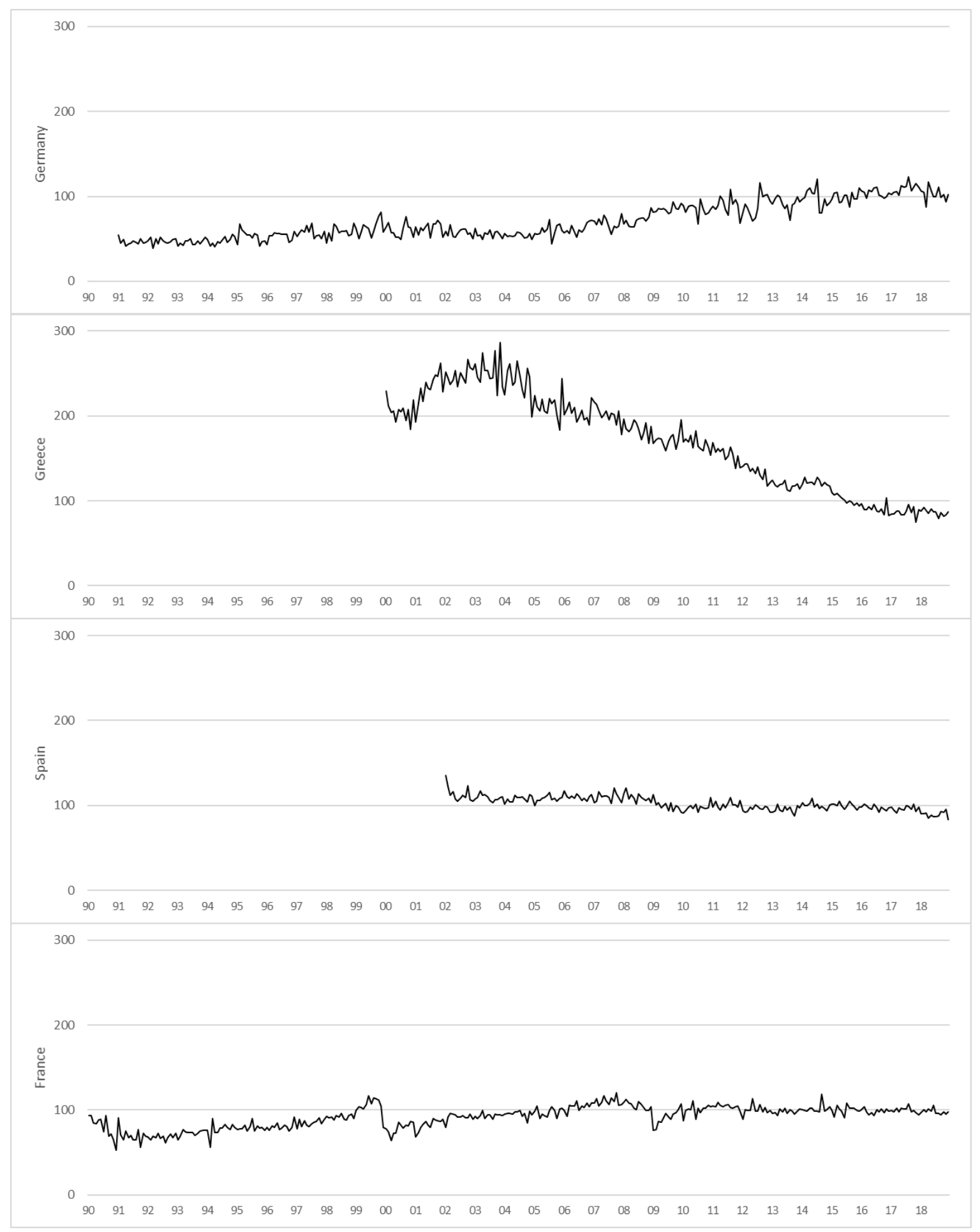

Source: Eurostat (2019a.), Production in industry - monthly data, available at: http://appsso.eurostat.ec.europa.eu/nui/show.do?dataset=sts inpr m\&lang=en [23 April 2019] 
Figure 3. Manufacture of beer, Index $(2015=100)$

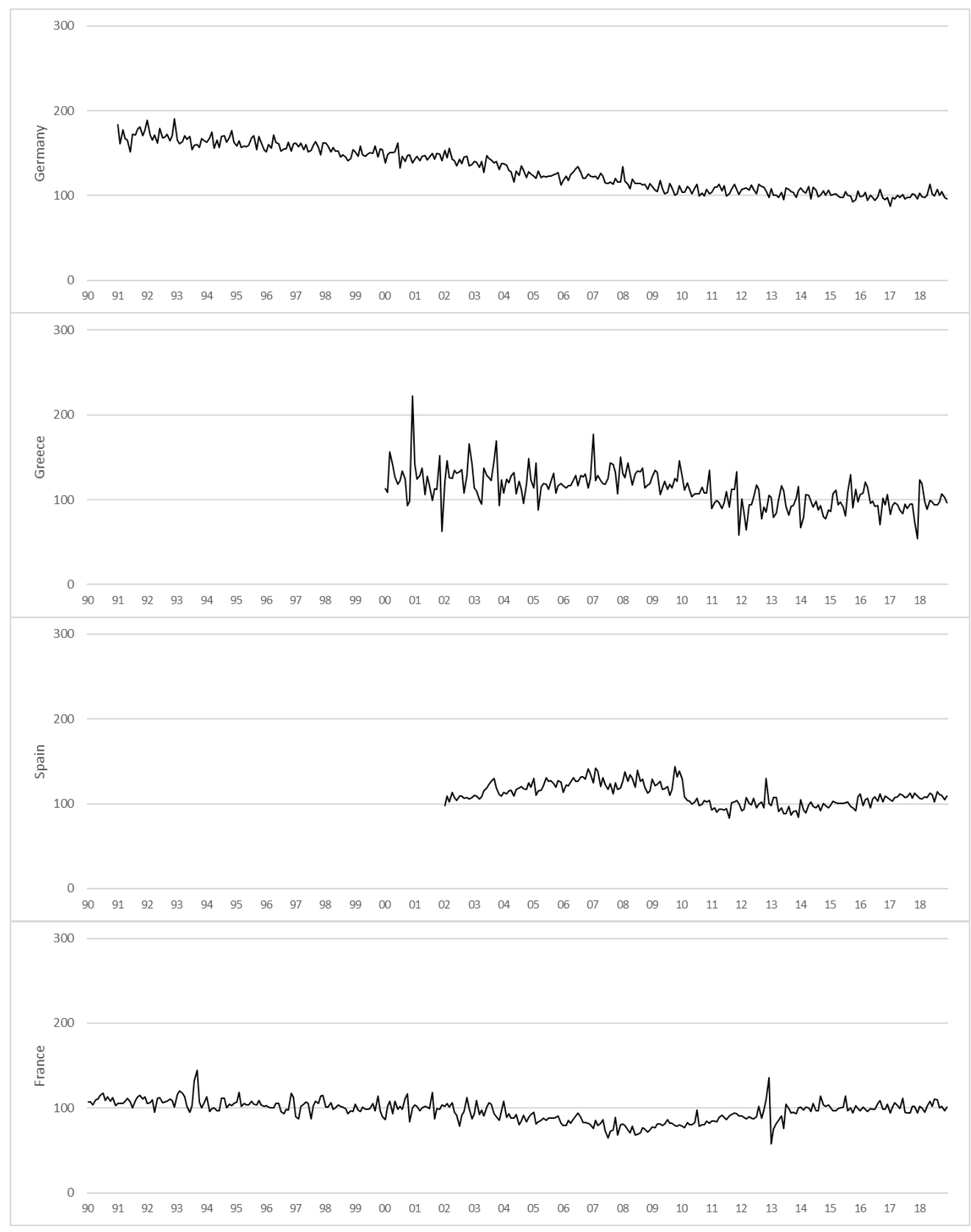

Source: Eurostat (2019a.), Production in industry - monthly data, available at: http://appsso.eurostat.ec.europa.eu/nui/show.do?dataset=sts inpr m\&lang=en [23 April 2019] 